\title{
Energy audit of paddy cultivation practices in Kokan region of Maharashtra
}

\section{R.V. POWAR, P.U. SHAHARE, V.V. AWARE AND A.A. DEOGIRIKAR}

Received : 04.05.2017; Revised : 12.09.2017; Accepted : 28.09.2017

See end of the Paper for authors' affiliation Correspondence to :

\section{R.V. POWAR}

Department of Farm Machinery and Power, College of Agricultural Engineering and Technology, Dr. Balasaheb Sawant Kokan Krishi Vidyapeeth Dapoli, RATNAGIRI (M.S.) INDIA Email : ranjitpowar56@gmail. com
ABSTRACT : This study highlights the energy consumption pattern of paddy cultivation practices followed in Kokan region of Maharashtra. The study data were collected from eight regional research stations of Balasaheb Sawant Kokan KrishiVidyapeeth, Dapoli. The net energy, specific energy, energy output input ratio,energy productivity and water productivity for paddy cultivation was found to be $61738.52 \mathrm{MJ} / \mathrm{ha}, 0.86 \mathrm{MJ} / \mathrm{kg}, 2.22,1.16 \mathrm{~kg} / \mathrm{MJ}$ and $9.33 \mathrm{~kg} / \mathrm{m}^{3}$, respectively. The cost per energy input and cost per energy output was found to be 19.99 Rs./MJ, 0.8342 Rs./MJ, respectively. Diesel fuel contributed highest share of input energy for paddy cultivation. Seed (52\%) contributed highest share of output energy, it immediately followed by straw $(48 \%)$. The contribution of indirect energy $(53.64 \%)$ was higher than that of the direct energy $(46.16 \%)$. In direct energy, the highest share of diesel fuel (82\%) as well as in indirect energy chemical fertilizers (49\%) contributed highest share. The share of non renewable energy $(72.86 \%)$ was found to be more than that of renewable energy $(27.14 \%)$. Water contributed highest share (46\%) to renewable energy and it immediately followed by human energy (30\%) stand on second position.Diesel fuel (52\%) contributed highest share to non renewable energy used and it followed by chemical fertilizers (30\%). The costs of different sources of input energy used in paddy cultivation were $19.995 \mathrm{Rs}$./MJ and that of output energy from paddy cultivation was 0.8342 Rs./MJ.

- KEY WORDS : Energy equivalent, Energy indices, Energy sources, Cost economics

-HOW TO CITE THIS PAPER : Powar, R.V., Shahare, P.U., Aware, V.V. and Deogirikar, A.A. (2017). Energy audit of paddy cultivation practices in Kokan region of Maharashtra. Internat. J. Agric. Engg., 10(2) : 647-654, DOI: 10.15740/HAS/IJAE/10.2/647-654. 